\title{
The Putative Secreted Serine Protease Chp-7 Is Required for Full Virulence and Induction of a Nonhost Hypersensitive Response by Clavibacter michiganensis subsp. sepedonicus
}

\author{
Riitta Nissinen, ${ }^{1}$ Yunjian Xia, ${ }^{1}$ Laura Mattinen, ${ }^{1}$ Carol A. Ishimaru, ${ }^{2}$ Dennis L. Knudson, ${ }^{3}$ \\ Susan E. Knudson, ${ }^{3}$ Mary Metzler, ${ }^{4}$ and Minna Pirhonen ${ }^{1}$ \\ ${ }^{1}$ Department of Applied Biology, University of Helsinki, PO Box 27, 00014 Helsinki, Finland; ' ${ }^{2}$ Department of Plant Pathology, \\ University of Minnesota, St. Paul, MN, U.S.A.; ${ }^{3}$ Department of Bioagricultural Sciences and Pest Management, \\ Colorado State University, Ft. Collins, CO, U.S.A.; ${ }^{4}$ Department of Biosciences, University of Helsinki, 00014 Helsinki, Finland
}

Submitted 9 August 2008. Accepted 21 March 2009.

\begin{abstract}
Molecular biological studies on Clavibacter michiganensis subsp. sepedonicus, the causal agent of bacterial ring rot of potato, have gained greater feasibility due to the recent availability of whole genomic sequences and genetic tools for related taxa. Here, we describe the first report of construction and characterization of a transposon (Tn) mutant library of $C$. michiganensis subsp. sepedonicus sp. strain R10. Since virulence of $\mathrm{R} 10$ in potato has been shown previously to be associated with elicitation of a nonhost hypersensitive response (HR), the mutant library was screened initially for loss of HR in tobacco. The screen identified two HR-negative mutants containing Tn insertions within the same gene, CMS2989 (chp-7), although at distinct locations. chp-7 is one of 11 pat-1 homologs in $C$. michiganensis subsp. sepedonicus. HR-negative mutants of R10 multiplied to the same extent as wild type in planta but were less virulent in potato. Complementation with $c h p-7$ restored virulence as well as the HR phenotype. Together, these findings demonstrate a role for chp-7 in $C$. michiganensis subsp. sepedonicus-plant interactions.
\end{abstract}

Clavibacter michiganensis subsp. sepedonicus is a grampositive phytopathogenic bacterium and one of five subspecies of the actinobacterial plant-associated species Clavibacter michiganensis (Davis et al. 1984; Holt et al. 1994). All known C. michiganensis subspecies impact agriculturally important crops such as tomato, potato, and alfalfa, have a limited host

This paper is dedicated to the memory of Dennis L. Knudson, who sadly passed away during its preparation.

Current address for R. Nissinen: Department of Microbial Ecology, University of Groningen, P.O. Box 14, 9750 AA Haren, the Netherlands.

Current address for Y. Xia: Department of Plant Biotechnology, Northeast Agricultural University, P.O. Box 260, Harbin, China.

Current address for S. E. Knudson: Department of Microbiology, Immunology and Pathology, Colorado State University, Ft. Collins, CO, U.S.A.

Current address for M. Metzler: Siltavoudintie 1 A 6, 00640 Helsinki, Finland

Corresponding author: Riitta Nissinen; E-mail: r.m.nissinen@rug.nl

* The $\boldsymbol{e}$-Xtra logo stands for "electronic extra" and indicates that a supplemental table and two supplemental figures are published online. range, and most are vascular pathogens causing wilt as the main symptom (Eichenlaub et al. 2006). C. michiganensis subsp. sepedonicus is the causal agent of bacterial ring rot of potato, an economically significant plant disease, and, for this reason, is subject to strict national and international quarantines. C. michiganensis subsp. sepedonicus is tightly plant-associated; it does not survive long in soil or as an epiphyte. The pathogen can establish latent (symptomless) infections as an endophyte for several plant generations until unknown factors lead to symptom outbreaks. Currently, cultivated potato is regarded as the sole host plant of C. michiganensis subsp. sepedonicus, although effective colonization and symptomatic infection has been reported to occur in Solanum nigrum (van der Wolf et al. 2005). Eggplant (Solanum melongena) and tomato (Lycopersicon esculentum) can be successfully infected in the laboratory and commonly serve as indicator plants in ring-rot testing (Elphinstone 2004).

Currently, two factors are known to be associated with virulence of $C$. michiganensis subsp. sepedonicus, cellulolytic activity and ability to induce a nonhost hypersensitive response (HR) (Heath 2000). A secreted cellulase, CelA, is known to be important for symptom development (Laine et al. 2000) but not involved in host colonization. In contrast, pathogenicity and ability to grow in planta correlate with the ability of $C$. $m i$ chiganensis subsp. sepedonicus strains to induce an HR on the nonhost plant tobacco (Nicotiana tabacum) (Nissinen et al. 1997). Strains that are unable to induce an HR are nonpathogenic and unable to multiply in planta. The HR phenotype is associated with one or more proteins secreted by the pathogen, but the identity and mode of action of these proteins in disease development are not known.

C. michiganensis subsp. sepedonicus and other actinobacterial plant pathogens are still relatively poorly characterized, mostly due to their slow growth rates and the lack of suitable molecular tools, which have made them highly challenging research subjects. However, knowledge on virulence strategies of plant-associated actinobacteria has expanded rapidly in the last several years, since genomic sequences of two subspecies of C. michiganensis (subsp. michiganensis [Gartemann et al. 2008] and subsp. sepedonicus [Bentley et al. 2008]), and a related actinobacterial plant pathogen, Leifsonia xyli subsp. xyli (Monteiro-Vitorello et al. 2004) became available. Further, development of a transposon (Tn) mutagenesis system 
for C. michiganensis (Kirchner et al. 2001) combined with genomic sequence information has enabled large-scale studies on these pathogens.

In this paper, we describe construction and characterization of a Tn mutant library of $C$. michiganensis subsp. sepedonicus and identify a role in virulence and HR induction of a putative secreted protease from the Pat-1 family (Burger et al. 2005).

\section{RESULTS}

\section{Tn library construction and characterization.}

A mutant library of $C$. michiganensis subsp. sepedonicus sp. strain R10 was constructed, using the arthrobacterial Tn1409C $\beta$ (Gartemann and Eichenlaub 2001) with slight modification of the mutagenesis protocol described by Kirchner and associates (2001). Most $C$. michiganensis subsp. sepedonicus strains, including the type strain ATCC33113, are highly mucoid, making cell preparations and isolation of individual colonies on agar plates very difficult. Thus, we chose to use the previously characterized wild-type strain R10, which is highly virulent but nonmucoid (Nissinen 2000). As C. michiganensis subsp. sepedonicus has been reported to be a highly homogenous subspecies (Brown et al. 2001; Louws et al. 1998), we anticipated limited sequence divergence between R10 and the sequenced strain ATCC33113 (Bentley et al. 2008). Optimal Tn mutagenesis of $C$. michiganensis subsp. sepedonicus was achieved by optimizing conditions for preparation of electrocompetent cells and parameters for electroporation (details below). Unlike in C. michiganensis subsp. michiganensis (Kirchner et al. 2001), we found no apparent difference in transformation rates, whether methylated (from Escherichia coli DH5 $\alpha$ ) or nonmethylated DNA (from GM2163) was used. Maximal transformation rates were in the range of $2.5 \times 10^{4} \mathrm{CFU}$ per $1 \mu \mathrm{g}$ of DNA. In total, 30 electroporations yielded a library of 2,100 Tn mutants. The individual mutants were regrown and stored for later use in multititer plates containing YGM (De Boer and Copeman 1980) and 10\% glycerol.

To evaluate the effectiveness of $\operatorname{Tn} 1409 \mathrm{C} \beta$ for mutagenesis of R10, 408 junction sites of R10 Tn mutants were sequenced. The analyzed data set was limited to 275 Tn mutants for which high-quality sequence reads were obtained. Insertions were localized within insertion (IS) elements and other repeated sequences, coding sequences (CDS), and intergenic sequences. Insertions into repeated sequences were eliminated from the data set, as their location could not be assigned unequivocally. The distribution of the remaining 221 insertions is summarized in Table 1. Tn insertions were distributed throughout the chromosome and within the two plasmids pCSL1 and pCS1. Insertions into pCS1 and pCSL1 were more frequent than insertions into the chromosome. Only $1 \%$ of the 3,058 CDS present in the reference strain ATCC33113 were disrupted in strain R10. In contrast, Tn $1409 \mathrm{C} \beta$ inserted into 27 and $20 \%$ of the CDS in pCS1 and pCSL1, respectively. Many of the insertions $(52 \%)$ were located within relatively low GC regions of the genome or of specific genes. This bias was especially evident in the chromosomal mutations, in which $77 \%$ of the inserts were in low-GC regions. Some regions of the genome contained multiple Tn $1409 \mathrm{C} \beta$ insertions. For example, $55 \%$ of the 89 mutations in pCS1 were located in only $18 \mathrm{CDS}$.

Although the overall percentage of mutants carrying mutations within annotated genes was low, several interesting mutants were identified (Supplementary Table 1). Tn insertions were identified at or very near the pat-1 homologs on pCS1 $(\mathrm{CDS}=\mathrm{pCS} 0022, \mathrm{pCS} 0037)$ and on pCSL1 $(\mathrm{CDS}=$ pCSL0117). Mutant L11E, (=Cms.R10.YB4) contained Tn1409C $\beta$ within CMS2989, one of the eight chromosomal pat-1 homologs discovered in C. michiganensis subsp. sepedonicus (Bentley et al. 2008). Insertions directly into celA (pCS0061) were also identified.

\section{Isolation and characterization of $\mathrm{HR}$ negative mutants.}

As the HR-negative phenotype has been associated with reduced virulence of $C$. michiganensis subsp. sepedonicus, we screened the Tn mutant library for induction of HR in N. tabacum cv. Samsun, with the goal of isolating HR-negative mutants. After a preliminary screening round, we identified 20 mutants with a severely weakened or negative HR phenotype. Of these 20 mutants, two consistently HR-negative mutants, O10A and L11E, were chosen for further analysis. Both of these mutants grew normally in rich and in YGM (De Boer and Copeman 1980) and were cellulase-positive in plate assays (results not shown) but failed consistently to induce HR in tobacco (Fig. 1).

Tn insertion sites of L11E and O10A were resolved by arbitrary polymerase chain reaction (PCR). Sequencing revealed that both mutants contain insertions of $\operatorname{Tn} 1409 \mathrm{C} \beta$ in the same CDS, CMS2989 (Fig. 2A), although at distinct locations (Fig. 2B). Tn1409C $\beta$ insertion sites were 318 and 581 bp downstream from the predicted translation initiation site of chp-7 for L11E and O10A, respectively. Both mutants have an 8-bp target sequence duplication typical of Tn1409 (Kirchner et al. 2001) at the insertion site (Supplementary Fig. 1) and both contain TAACG as part of the repeat. CMS2989 is also known as chp-7, for chromosomal homology of Pat-1 (Bentley et al. 2008), and the name chp-7 will be used in this paper.

The affected gene, chp-7, is a member of a protein family homologous to the pathogenicity determinant and putative serine protease pat-1 of $C$. michiganensis subsp. michiganensis (Burger et al. 2005; Dreier et al. 1997). C. michiganensis subsp. michiganensis and C. michiganensis subsp. sepedonicus contain multiple homologs of pat-1 with varying similarities

Table 1. Distribution of Tn1409C $\beta$ insertions in Clavibacter michiganensis subsp. sepedonicus sp. strain R10

\begin{tabular}{|c|c|c|c|}
\hline Category & Chromosome & pCS1 & pCSL1 \\
\hline Number of insertions assigned unambiguously & 84 & 89 & 48 \\
\hline Number in coding sequences (CDS) & 40 & 18 & 23 \\
\hline Number with multiple insertions & 9 & 10 & 8 \\
\hline Number with insertions in low-GC and atypical sequences & 25 & 11 & 5 \\
\hline Number in intergenic sequences & 33 & 39 & 12 \\
\hline Number of low-GC and atypical sequences & 31 & 23 & 2 \\
\hline Total number of insertions (intergenic, CDS, and multiples) in low-GC and atypical sequences & 65 & 39 & 12 \\
\hline Percent of total assigned insertions located within low-GC and atypical sequences & 77 & 44 & 25 \\
\hline Percent of total insertions assigned to CDSs & 30 & 56 & 75 \\
\hline Total number of CDS in replicon ${ }^{\mathrm{a}}$ & 3,058 & 89 & 117 \\
\hline Percent CDS disrupted & 1 & 27 & 20 \\
\hline Percent CDS disrupted in low-GC sequences & 63 & 58 & 21 \\
\hline
\end{tabular}

${ }^{a}$ Bentley et al. 2008. 
(Bentley et al. 2008; Gartemann et al. 2008). chp-7 has highest similarity (86\% amino acid identity) to PCS0037, a Pat-1 homolog in the circular plasmid pCS1 of $C$. michiganensis subsp. sepedonicus and to Pat-1 family members pat-1 (YP_001220724) and phpA of C. michiganensis subsp. michiganensis (77 and $71 \%$ identity, respectively). In addition to $C$. michiganensis subsp. michiganensis and $C$. michiganensis subsp. sepedonicus, homologs of chp-7 are also present in Leifsonia xyli subsp. xyli (YP_063162), in Xanthomonas oryzae pv. oryzae strains KACC10331 (AAW74240), PX099A (ACD60846), and MAFF311018 (YP_449930), in Acidovorax avenae pv. citrulli (ABM33827.1), and in X. campestris pv. vesicatoria $85-10(\mathrm{CAJ} 26155.1$ and CAJ26156.1, $\mathrm{xcv} 4424$ and

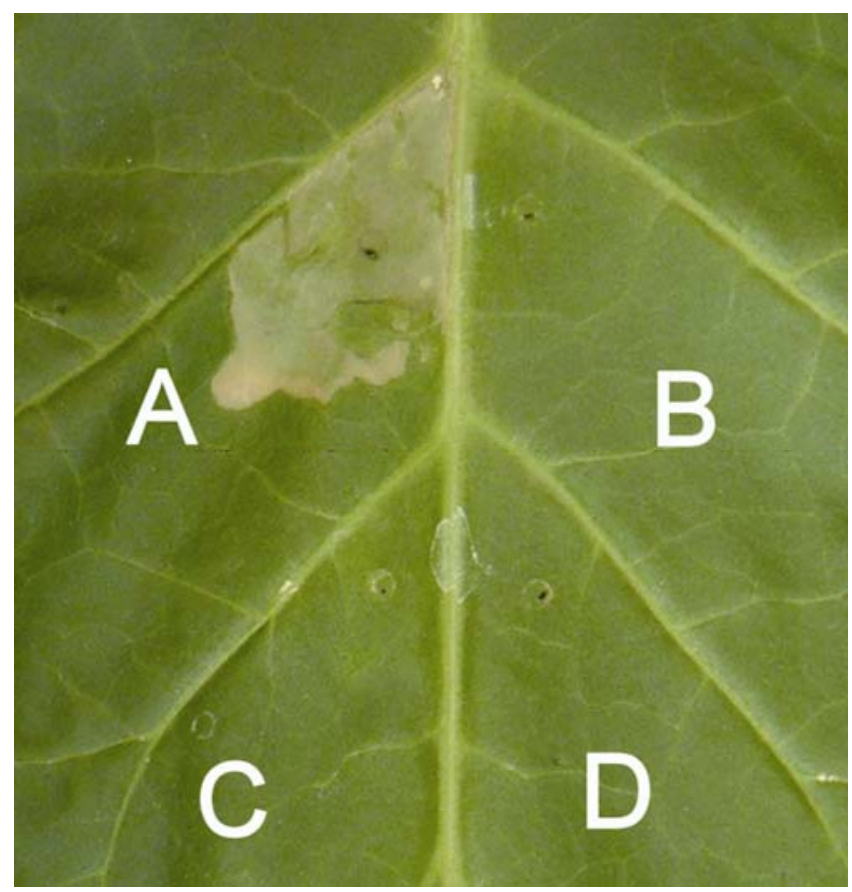

Fig. 1. Wild-type strain R10 and mutants L11E and O10A assayed for induction of hypersensitive response on tobacco (Nicotiana tabacum cv. Samsun). Bacterial suspensions in $50 \mathrm{mM} \mathrm{KPi} \mathrm{(pH} \mathrm{7.0)} \mathrm{were} \mathrm{infiltrated}$ into leaf intercellular spaces with a sterile syringe. Photo was taken $48 \mathrm{~h}$ postinoculation. A, Wild-type strain R10, B, buffer control, C, mutant O10A, and D, mutant L11E. xcv4425, respectively). The homologous protein in $X$. campestris pv. vesicatoria seems to be inactivated by frameshift, as two successive open reading frames (ORF), xcv4424 and $x c v 4425$, show clear similarity to $\mathrm{N}$-terminal and C-terminal parts of Chp-7, respectively (Supplementary Fig. 2).

Chp-7 has a predicted molecular mass of $29.9 \mathrm{kDa}$ and contains a signal peptide sequence of 35 amino acids (SignalPhidden Markov model probability of 1.000$)$, with a predicted mature protein of $26.5 \mathrm{kDa}$. Like other Pat-1 family members, Chp-7 contains two consensus motifs of serine proteases at position 94 (TAKHC) and at position 226 (ATQRGDSGG), the latter including the predicted catalytic serine. Additionally, Chp-7 has a putative membrane-anchoring motif, LPGSGA, close to its C-terminus, present only in certain Pat-1 family members (Garteman et al. 2008). As Chp-7 is truncated at H106 in mutant L11E and at Y194 in O10A, both mutants lack the protease catalytic site as well as the membrane-anchoring site and are, thus, unlikely to have any protease activity or proper localization (Fig. 2B). Both mutants could putatively produce truncated Chp-7 proteins, with the intact $\mathrm{N}$-terminus of Chp-7 followed by three (in mutant O10A) or ten (in L11E) Tn 1409 C $\beta$-derived amino acids followed by a stop codon in frame.

chp 7 resides in a region of the $C$. michiganensis subsp. sepedonicus genome with a low percentage of GC (Bentley at al. 2008); the percent GC of chp-7 is only $57 \%$, remarkably lower than the average of $73 \%$ in the ATCC 33113 reference chromosome. chp-7 is located immediately downstream of an IS element (Bentley at al. 2008) and is followed by a putative protein and another pat-1 family member, CMS2991. As chp-7 and the adjacent genes are transcribed in opposite directions, chp-7 is very likely a single-gene operon (Fig. 2A).

\section{Analysis of insertion site}

\section{of Tn1409C $\beta$ by PCR and Southern hybridization.}

The insertion site and orientation of Tn $1409 \mathrm{C} \beta$ in chp-7 in both mutants was checked by PCR with primer pairs TnpAOut-Pat1F and TnpAOut-Pat1R, in which TnpAOut is located in the tnpA region in $\mathrm{Tn} 1409 \mathrm{C} \beta$ and primers Pat $1 \mathrm{~F}$ and Pat1R at the $5^{\prime}$ and $3^{\prime}$ ends of chp-7, respectively. As only primer pair TnpAOut-Pat1F yielded PCR product in both mutants, we concluded that the Tn was inserted in the same orientation in both mutants, and the insertion sites were 325 and $588 \mathrm{bp}$ from the predicted translation initiation site for mutants L11E and O10A, respectively.

$1 \mathrm{~kb}$

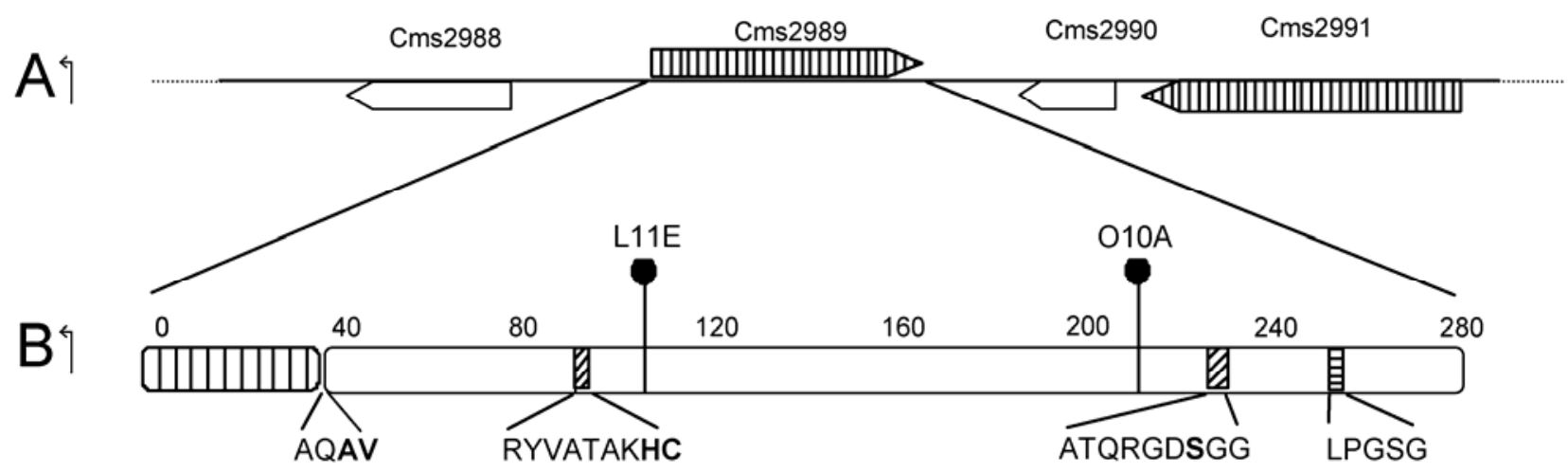

Fig. 2. The chp-7 (CMS2989) A, genomic neighborhood and B, predicted translation product, with main features and Tn $1409 \mathrm{C} \beta$ insertion sites indicated. A, Hatched coding sequences are pat-1 family members; B, Tn $1409 \mathrm{C} \beta$ insertion sites for respective mutants are marked with black lollipops. Also marked are a putative signal peptide processing site (AQAV) with predicted cleavage between A and $\mathrm{V}$, consensus motifs of the trypsin family of serine proteases (RYVATAKHC and GDSGG), the latter containing the active site serine, and putative membrane-anchoring motif (LPGSGA). Numbers refer to amino-acid residues in protein. 
The presence and single site insertion of Tn $1409 \mathrm{C} \beta$ in mutants was confirmed by Southern blotting. Total DNA of the wild-type strain R10 and mutants O10A and L11E was hybridized with probes CMS2989int and Tn1409, derived from chp-7 and Tn1409C $\beta$, respectively (details below). Hybridization with probe Tn1409 yielded one band of approximately $800 \mathrm{bp}$ from both mutants, indicating presence of Tn $1409 \mathrm{C} \beta$ in both mutant strains (Fig. 3A). When hybridized with probe CMS2989, one band of $3.8 \mathrm{~kb}$ was present in R10, while both O10A and L11E showed two separate bands, indicating insertion of Tn1409C $\beta$ into chp-7. An additional CMS2989specific high-molecular weight band was present in the two mutants as well as in the wild-type strain R10 (Fig. 3B). Based on genome sequence and restriction analysis, this is very likely a highly homologous gene in plasmid pCS1, PCS0037, also known as php-2.

\section{L11E and O10A produce truncated chp-7 transcripts.}

We used reverse transcriptase-PCR (RT-PCR) to check, whether mutants L11E and O10A were able to produce (truncated) transcripts of chp-7. Three primer pairs were designed with reverse primer upstream of the Tn insertion site in L11E and O10A or downstream of both insertion sites (discussed below). We detected a RT-PCR product in both mutants as well as wild-type strain with a primer pair located upstream of Tn insertion sites in both mutants, indicating that mutants were producing (truncated versions of) $\operatorname{chp} 7$ mRNA (Fig. 4). As expected, no PCR product was detected in RNA samples from mutants with the primer pair corresponding to almost full-size mRNA of chp-7 (Fig. 4, primer pair 1). Likewise, no product was detected in the L11E sample with a primer pair located downstream of the Tn insertion site in L11E, although a transcript was detected in mutant O10A and wildtype R10A.

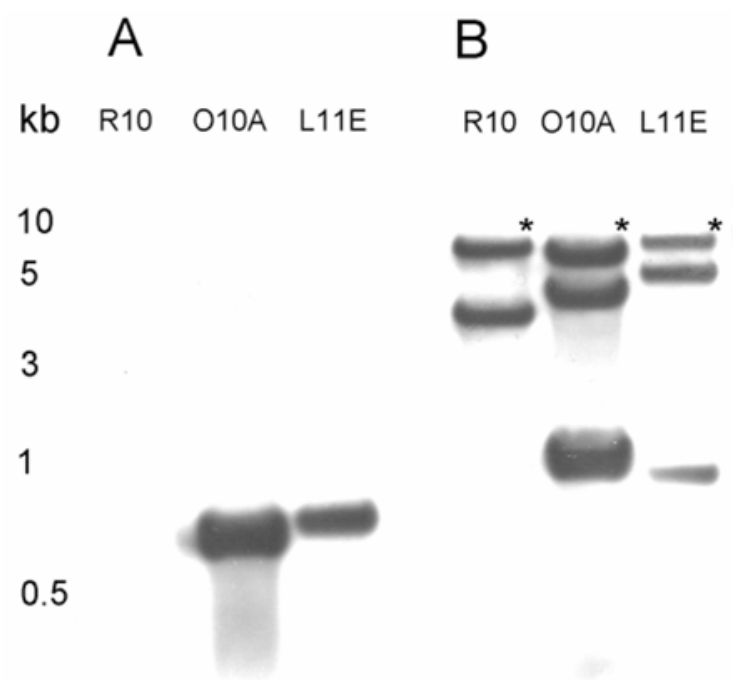

Fig. 3. Southern hybridization of Clavibacter michiganensis subsp. sepedonicus wild-type strainR10 and mutants L11E and O10A with probes derived from A, Tn1409C $\beta$ and $\mathbf{B}, c h p-7$. Total DNA of wild-type strain R10 and mutants L11E and O10A was isolated, digested with $\mathrm{Bam} \mathrm{H} 1$, and resolved by electrophoresis in $1 \%$ agarose gels. Tn1409C $\beta$ contains two sites for BamH1 (Kirchner et al. 2001). A, Tn1409C $\beta$-specific signal is present in both mutants but absent from wild-type R10, indicating presence of Tn1409C $\beta$ in both mutant strains. B, One chp-7-specific band of $3.8 \mathrm{~kb}$ is present in R10. Both O10A and L11E samples contain two separate bands, indicating insertion of $\operatorname{Tn} 1409 \mathrm{C} \beta$ (and subsequent introduction of additional Bam $\mathrm{H} 1$ cleavage sites) into chp-7. The high molecularweight band present in all three samples and denoted with an asterisk is very likely the highly homologous pat-1 family member PCS0037, present in plasmid pCS1. Molecular size is marked in kilobases $(\mathrm{kb})$.

\section{Secretomes of chp-7 mutants do not differ significantly} from wild type in vitro.

Based on the presence of a signal peptide sequence, Chp-7 is highly likely to be a secreted protein. As a putative serine protease, it could potentially be involved in protein processing. To determine whether mutations in $c h p-7$ have a major pleiotrophic effect on other R10 secreted proteins, the secretomes of R10, L11E, and O10A were compared. R10 and mutants L11E and O10A were grown in liquid cultures under conditions known to support production of HR-inducing proteins (Nissinen et al. 1997). After 36 h, supernatants were harvested and concentrated for extracellular proteins, and proteins were resolved by two dimensiohnal polyacrylamide gel electrophoresis. The experiment was repeated four times. No drastic or consistent differences were detected in the secretomes of mutant strains as compared with wild type (results not shown).

\section{$\mathrm{L11E}$ and $010 \mathrm{~A}$ are reduced in virulence but} are not impaired in their ability to multiply in planta.

We tested the ability of L11E and O10A to induce disease symptoms in eggplant (Solanum melongena cv. Black Beauty). After 14 days, disease symptoms were clearly visible in plants infected with wild-type strain R10; plants showed chlorosis, wilting, and stunting. Symptoms were significantly reduced in plants infected with mutant L11E. Plants infected with mutant O10A showed slightly reduced symptoms but were not statistically different from those of R10 (Fig. 5A). The virulence assay was repeated four times with similar results. Severity of disease symptoms produced by mutant L11E was consistently lower than those by R10, but, in three cases out of four, mutant O10A exhibited slightly less virulence that was statistically indistinguishable from wild type. Despite reduced virulence, both O10A and L11E consistently established population densities similar to R10 in planta (Fig. 5B).

The virulence of L11E and O10A was also tested in S. tuberosum cv. Superior, which is highly susceptible to bacterial ring rot. Ten weeks after infection, nine of 10 plants inoculated with R10 exhibited severe disease symptoms, with an average disease severity of $76 \%$ (Fig. 6). Both mutants were clearly impaired in inducing both disease symptoms (chlorosis, wilting, and necrosis) and size reduction. Again, the difference in

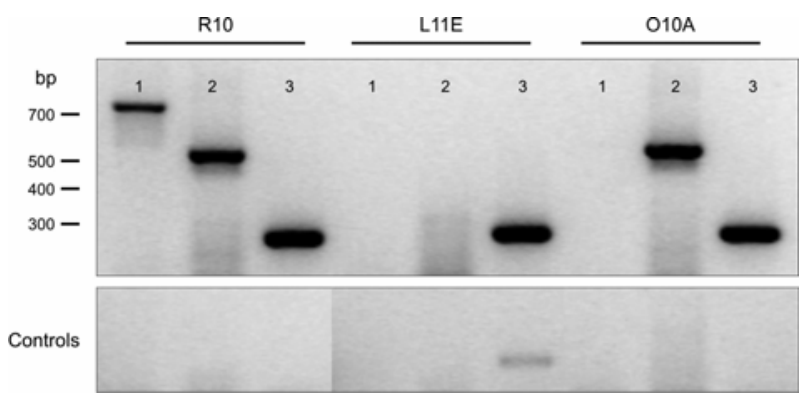

Fig. 4. Reverse transcriptase-polymerase chain reaction (RT-PCR) analysis of chp-7 transcripts in wild-type strainR10 and mutants L11E and O10A. We used RT-PCR to detect chp-7 transcripts in R10, L11E, and O10A. Three primer pairs were designed, corresponding either to nearly full-size transcript (primer pair 1) or with reverse primer upstream of the transposon insertion site in O10A (primer pair 2) or L11E (primer pair 3). No PCR product was detected in RNA samples from either of the mutants with primer pair 1 . However, a RT-PCR product was detectable in a mutant O10A sample with primer pair 2 and in both mutant samples (as well as in a wild-type strain R10 sample) with primer pair 3, indicating that mutants were producing truncated versions of $c h p 7$. mRNA DNAasetreated RNA prior to reverse transcriptase treatment was used as a control. In each experiment, some background was visible, indicating residual DNA in the samples. However, the background was in different samples in different runs and, for each strain, we could observe clear positive RT-PCR results without background. The RT-PCR was repeated four times. 
virulence was not reflected in population densities. Although in planta population densities of mutants were slightly lower (3.2 and $2.2 \times 10^{9} \mathrm{CFU}$ per gram of plant tissue for O10A and L11E, respectively) than R10 $\left(4.3 \times 10^{9} \mathrm{CFU} / \mathrm{g}\right)$, the differences were not statistically significant.

\section{Complementation of L11E}

with $c h p-7$ restores HR and full virulence.

For complementation of virulence and HR, the coding region and the predicted promoter area of $c h p-7$ was cloned into an E. coli-Clavibacter shuttle vector, pHN216 (Laine et al. 1996). The resulting construct pHNPat $1 \mathrm{Cms}$ was used to transform L11E, the mutant with the more profound virulence phenotype. Three individual transformants of L11E carrying pHNPat $1 \mathrm{Cms}$ were tested for restoration of HR and virulence. When assayed for induction of HR in tobacco, all transformants carrying pHNPat $1 \mathrm{Cms}$ induced an HR similar to R10, whereas L11E and L11E transformed with cloning vector pHN216 did not (Fig. 7A). Likewise, when tested for virulence in eggplants, the complemented L11E transformants all induced disease symptoms statistically indistinguishable from R10, confirming that $c h p-7$ is involved in symptom development (Fig. $7 \mathrm{~B}$ and $\mathrm{C})$.
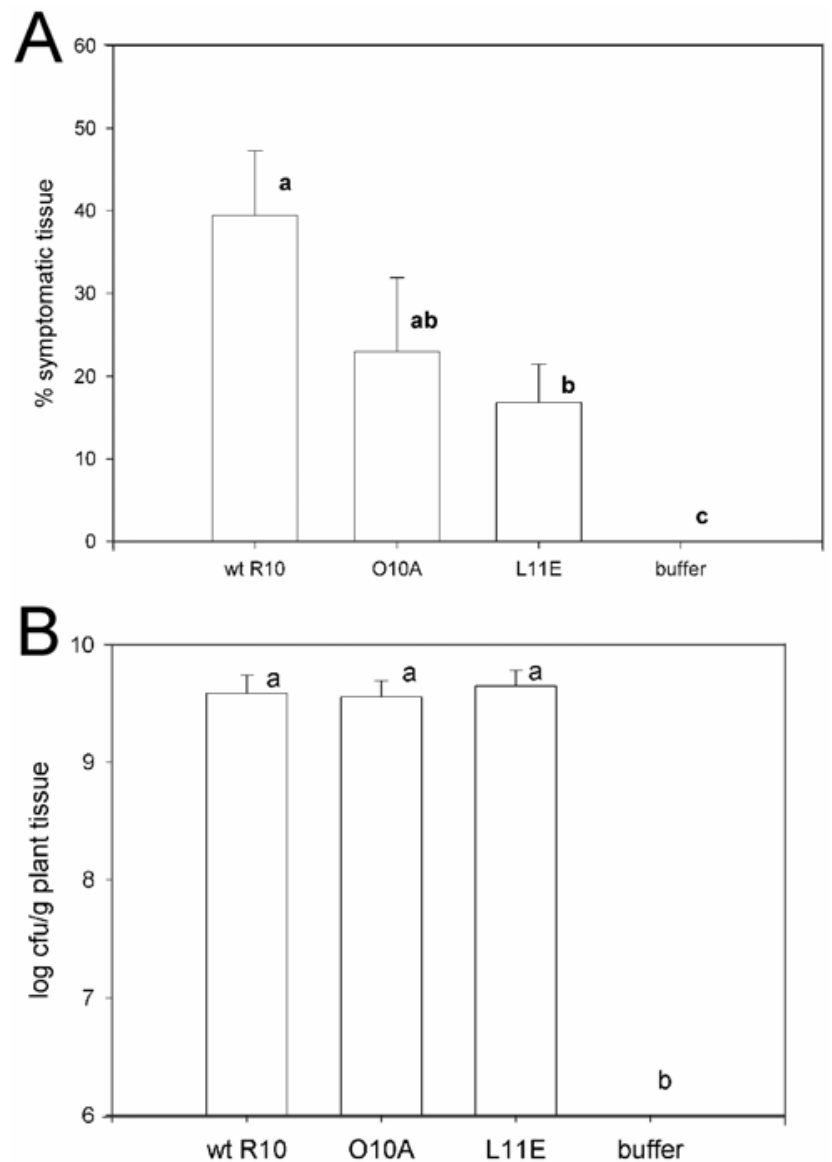

Fig. 5. Virulence and population densities in planta of Clavibacter michiganensis subsp. sepedonicus wild-type strain R10 and mutants O10A and L11E in eggplant. Eggplant stems were inoculated with bacterial suspensions prepared from individual strains, and disease index and bacterial numbers were determined 14 days after inoculation. The data presented represents mean values and standard error from a typical experiment analyzed by analysis of variance followed by Tukey's honestly significant differences test. A, Disease severity (\%) in eggplants infected with R10, O10A, and L11E. Values marked with the same letter do not differ significantly $(P=0.05)$. B, Population densities of R10, O10A, and L11E expressed as mean log CFU per gram of plant tissue, as determined by dilution plating. Values marked with the same letter do not differ significantly $(P=0.05)$.

\section{DISCUSSION}

In this paper, we describe the optimization of a Tn mutagenesis system and construction of a Tn mutant library with Tn1409C $\beta$ (Kirchner et al. 2001) for C. michiganensis subsp. sepedonicus sp. strain R10. Screening of the library for mutants affected in ability to elicit an HR in a nonhost plant and disease in eggplant, a commonly used indicator plant used in bacterial ring rot diagnosis, yielded several mutants for further study. Further, we demonstrate a role for Chp-7, one of several putative secreted serine proteases of the Pat-1 family, in C. michiganensis subsp. sepedonicus-plant interactions.

The Tn mutagenesis system developed for $C$. michiganensis subsp. michiganensis by Kirchner and associates (2001) was functional in $C$. michiganensis subsp. sepedonicus and produced mutants for plant-microbial interaction studies. As reported previously, the glycine concentration used for producing competent cells was critical for optimal transformation. Even with optimization, transformation efficiencies of $C$. michiganensis subsp. sepedonicus were much lower (10- to 1,000-fold) than those reported for $C$. michiganensis subsp. michiganensis. Multiple electroporations were necessary to obtain a library of 2,100 R10 mutants. Although the R10 mutant library described here represents only a small portion of what would be needed for saturation of the genome, it has significance as the first large scale set of $C$. michiganensis subsp. sepedonicus mutants ever characterized in planta.

Tn1409C $\beta$, while clearly useful, has limitations as a mutagenesis tool for investigating the molecular biology of $C$. michiganensis subsp. sepedonicus. An ideal transposition system would insert randomly within genes of the target organism. However, based on sequence reads of $10 \%$ of the R10 mutant library, Tn1409C $\beta$ did not insert randomly into C. michiganensis subsp. sepedonicus. Transposition into IS elements was common; nearly $20 \%$ of the 275 mutants evaluated contained insertions within IS elements. Tn1409C $\beta$ would likely have greater utility for genomes that have fewer IS elements; $C$. $m i$ chiganensis subsp. sepedonicus contains a large number (106) of IS elements, whereas IS elements in C. michiganensis subsp. michiganensis are scarce (Bentley et al 2008; Gartemann et al 2008). There also appears to be a preference of transpositions into plasmids and regions of relatively lower GC content.

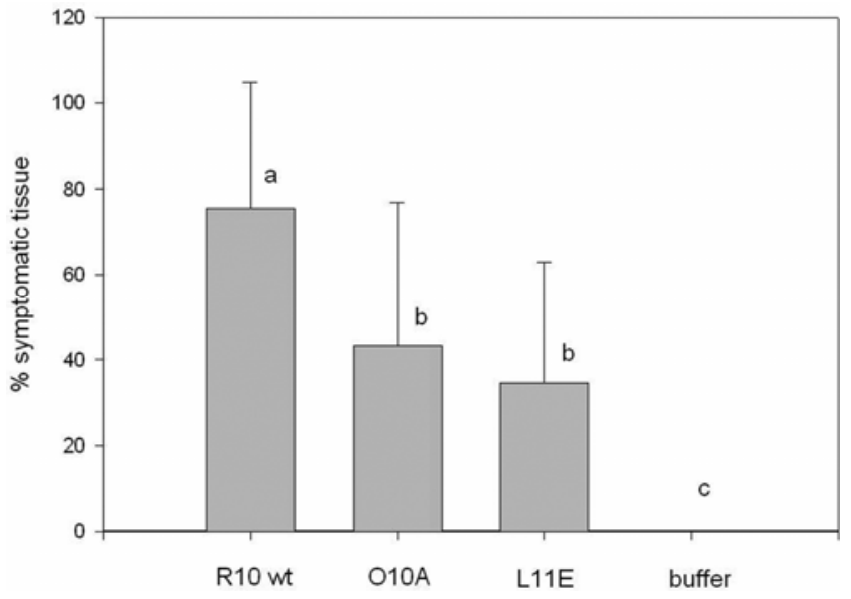

Fig. 6. Virulence of Clavibacter michiganensis subsp. sepedonicus wildtype strainR10 and mutants L11E and O10A in Solanum tuberosum cv. Superior. Roots of micropropagated potato plants were inoculated with bacterial suspensions prepared from individual strains and scored for disease symptoms 77 days after inoculation. The data presented represent mean values and standard error, analyzed by analysis of variance followed by Tukey's honestly significant differences test. Values denoted with the same letter do not differ significantly $(P=0.05)$. 
Nonetheless, the apparent bias of Tn1409C $\beta$ for low-GC sequences was advantageous, as many pat-1 homologs, like CMS2989, are located within genomic islands characterized by lower GC.

Pathogenicity assays of $C$. michiganensis subsp. sepedonicus are time consuming and require several plants per test strain. Thus, based on previous work demonstrating a correlation between pathogenicity and HR-production (Nissinen et al. 1997), library screening was expedited by screening first for loss of HR induction in tobacco. This approach identified two HR-negative mutants containing $\mathrm{Tn}$ insertions within the same gene, CMS2989 (chp-7), although at distinct locations. Further screening demonstrated these mutants were also deficient in virulence. These findings are significant for three reasons. First, the HR phenotype was effective for informing studies on pathogenicity of $C$. michiganensis subsp. sepedonicus. Second, redundancy of pat-1 homologs within the genome of $C$. michiganensis subsp. sepedonicus did not prevent the determination that a specific member of this family contributes to $C$. michiganensis subsp. sepedonicus-plant interactions. Thirdly, all pat-1 homologs do not contribute equally to HR and disease. This is suggested by the fact that mutants containing Tn insertions in three of the 11 pat-1 homologs in $C$. michiganensis subsp. sepedonicus were not identified as HR-deficient in tobacco.

HR induction has been associated with one or more proteins present in culture filtrates of R10 (Nissinen et al. 1997, 2001). Since $\operatorname{chp}-7$ is predicted to encode a secreted protein, Chp-7 might be produced in culture filtrates and perhaps be responsible for the HR phenotype of $C$. michiganensis subsp. sepedonicus in N. tabacum. However, as the constructed library is

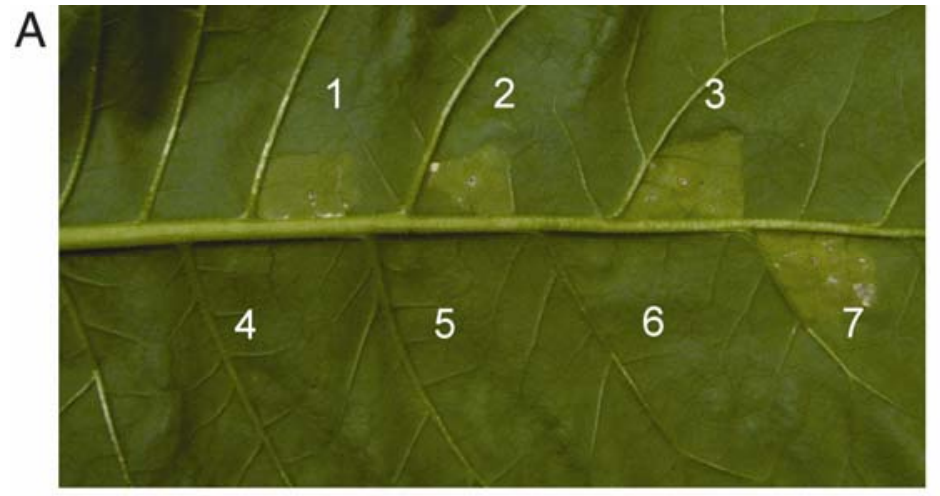

C

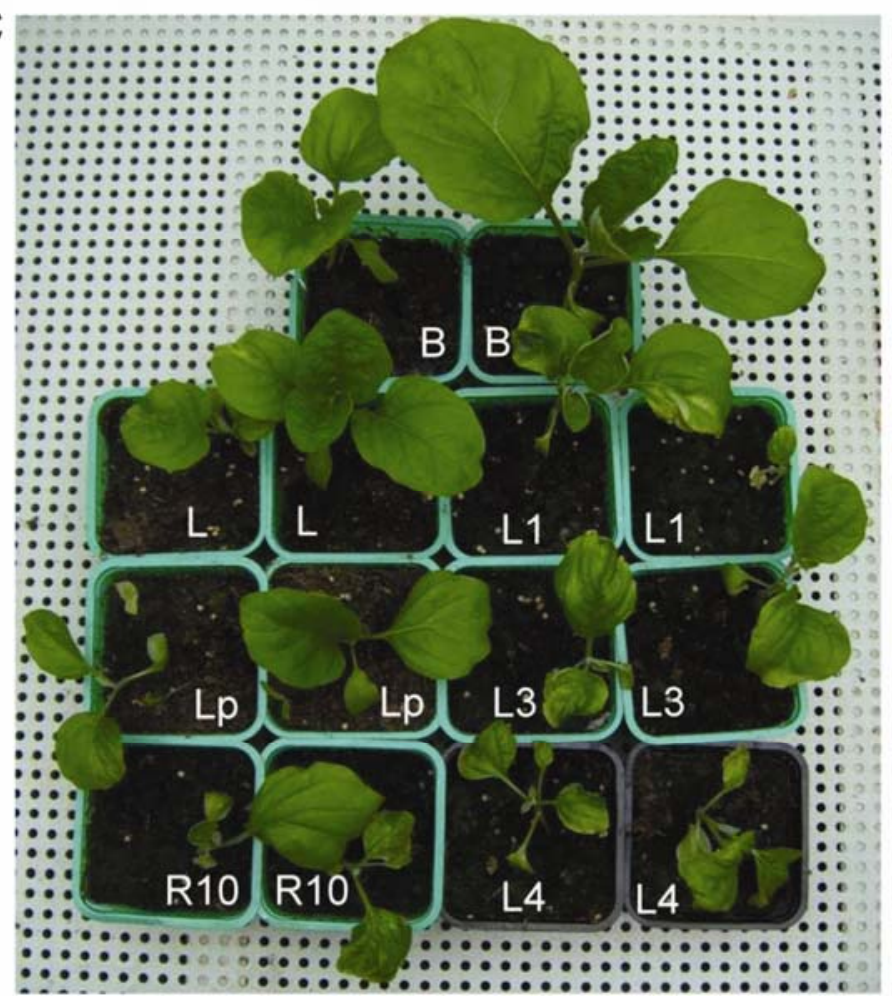

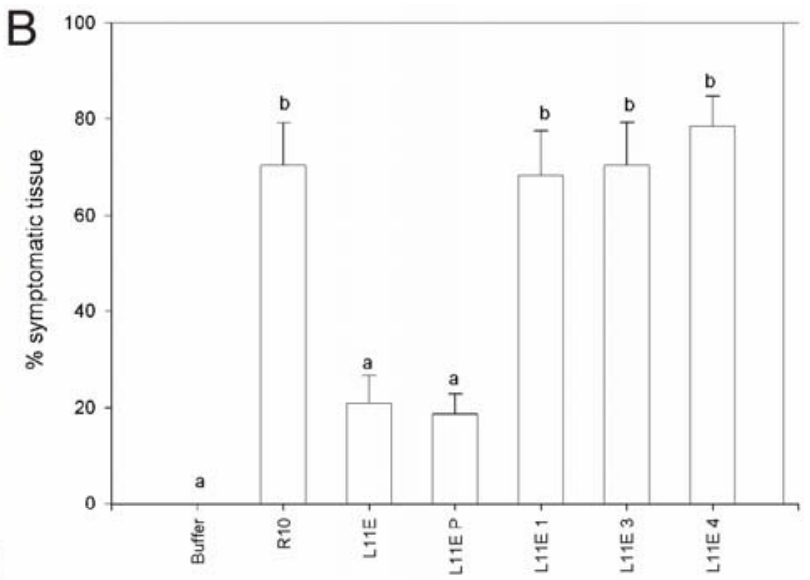

Fig. 7. Complementation of hypersensitive response (HR) and virulence of Clavibacter michiganensis subsp. sepedonicus mutant L11E by chp-7. A, Induction of HR in tobacco by wild-type strainR10, mutant L11E, and L11E transformed with vector pHN216 or with pHNPat1Cms carrying chp-7. Samples 1 to 3, L11E transformed with pHNPat1Cms (L11E1, L11E3 and L11E4); sample 4, buffer control; 5: L11E; 6, L11E transformed with pHN216; and 7, wild-type strain R10. Bacterial suspensions in $50 \mathrm{mM} \mathrm{KPi} \mathrm{(pH} \mathrm{7.0)} \mathrm{were} \mathrm{infiltrated} \mathrm{into} \mathrm{leaf} \mathrm{intercellular} \mathrm{spaces} \mathrm{with} \mathrm{a} \mathrm{sterile} \mathrm{syringe.} \mathrm{Photo} \mathrm{was} \mathrm{taken} 24 \mathrm{~h}$ postinoculation. B, Wild-type strain R10, mutant L11E, and L11E transformed with vector pHN216 (L11EP) or with pHNPat1Cms carrying chp-7 (L11E1, L11E3 and L11E4). Eggplants stems were inoculated with bacterial suspensions prepared from individual strains, and the disease index determined 14 days after inoculation (dpi). The data presented represent mean values and standard error from 10 plants, analyzed by analysis of variance followed by Tukey's honestly significant differences test. Values denoted with the same letter do not differ significantly $(P=0.05)$. C, Disease symptoms induced in eggplants by R10, mutant L11E (L), and L11E transformed with vector pHN216 (LP) or with pHNPat1Cms carrying chp-7 (L1, L3, and L4) or with sterile phosphate buffer (B). The photograph was taken 14 dpi. The plants presented represent typical results. 
not saturated, we cannot conclude that $\mathrm{Chp}-7$ is the sole HRassociated protein produced by R10. Additionally, our attempts to express chp-7 in E. coli were unsuccessful, as Chp-7 has a deleterious effect on $E$. coli M15 (data not shown). Thus, we cannot exclude the possibility that $\mathrm{Chp}-7$ functions in the processing of other secreted proteins, although we did not detect any major differences in secreted protein profiles between wild type and the mutants.

In subspecies michiganensis, induction of $\mathrm{HR}$ is associated with another member of the Pat-1 protein family, ChpG (Gartemann et al. 2008). Chp-7 and ChpG are relatively divergent. ChpG is more similar to CMS2909, another Pat-1 homolog located on the chromosome of $C$. michiganensis subsp. sepedonicus. However, the HR tests with subsp. michiganensis are routinely done in Mirabilis jalapa and subsp. sepedonicus has been tested in tobacco. Evaluating the HR phenotypes of Chp-7 and ChpG on M. jalapa and N. tabacum, respectively, might determine whether elicitation is plant specific. Interestingly, unlike mutants $\mathrm{L} 11 \mathrm{E}$ and O10A of C. michiganensis subsp. sepedonicus, ChpG mutants of C. michiganensis subsp. michiganensis are fully virulent (Gartemann et al. 2008).

In a recent study on in planta expression of putative virulence determinants of $C$. michiganensis subsp. sepedonicus, expression levels of $c h p-7$ were reported to be slightly lower in planta than in liquid NYB medium (Holtsmark et al. 2008). However, as the expression levels were based on an infiltrated, detached leaf assay, the test conditions might not have fully mimicked the in planta conditions of natural xylem-inhabiting cells of C. michiganensis subsp. sepedonicus. Additionally, one or more HR-inducing proteins can be readily isolated from supernatants of $C$. michiganensis subsp. sepedonicus cultures grown in liquid media (Nissinen et al. 1997), indicating that HR-associated genes, probably including chp-7, are expressed in standard laboratory medium.

Mutants O10A and L11E both contain Tn1409C $\beta$ insertions within the same gene, CMS2989, which is very likely the only gene in an operon (Fig. 2A). Still, mutant L11E caused consistently milder (statistically significantly different) disease symptoms in eggplant than O10A (Fig. 5A). In the highly susceptible potato cultivar Superior, however, the differences between the two mutants and R10 was clearly evident, measured either by size reduction (data not shown) or disease severity (Fig. 6). The puzzling differences between phenotypes in eggplant and potato might be related to differences in the Tn $1409 \mathrm{C} \beta$ insertion sites. RT-PCR demonstrated that both mutants produced truncated versions of $\operatorname{chp} 7$ transcript (Fig. 4). Thus, both mutations can result in translated albeit truncated proteins, but the mutant protein in L11E is missing almost two thirds of the original protein (174 amino acids of 280) whereas O10A is missing only 86 amino acids. Alternatively, it might be that mutant O10A is still able to produce and secrete a truncated protein while L11E cannot. Although both mutations theoretically yield truncated proteins, the resulting predicted protein in O10A contains only three Tn $1409 \mathrm{C} \beta$-derived amino acids, whereas L11E contains 10, which could have a deleterious effect on protein folding or secretion.
Both Chp-7 mutants L11E and O10A were affected in disease induction (Figs. 5A and 6), indicating that Chp-7 has a role in virulence. Since both mutants grew to wild-type levels in eggplant and potato, Chp-7 is clearly not required for multiplication in planta. This resembles the phenotype of the first described Pat-1-deficient mutant of $C$. michiganensis subsp. michiganensis. In that case, loss of pat- 1 was associated with drastically reduced disease symptoms in tomato, but in planta bacterial population densities were indistinguishable from the wild-type strain (Dreier et al. 1997). In contrast, another Pat-1 family member of subspecies michiganensis, $\mathrm{ChpC}$, is required for multiplication in host plants; the ChpC mutant shows drastically reduced population densities in planta and produces only very weak disease symptoms (Stork et al. 2008). However, unlike Chp-7 mutants, the ChpC mutant as well as Pat-1 mutants of $C$. michiganensis subsp. michiganensis remained HR positive, albeit on M. jalapa. Thus, the Pat-1 family members seem to be involved in interactions between $C$. michiganensis and plants and different family members seem to have specific roles and divergent phenotypes depending on host-pathogen specificity. C. michiganensis subsp. sepedonicus has 11 pat-homologs, eight of which are chromosomal, two are on plasmid pCS1, and one-pCSL0117, with high similarity to ChpC of subsp. michiganensis - is located on the linear plasmid pCSL1 (Bentley et al. 2008). Two of the chromosomal homologs seem to be inactive (Bentley et al., 2008).

In addition to the actinobacterial species $C$. michiganensis and Leifsonia xyli, pat- 1 homologs are present in plant pathogenic $\gamma$-Proteobacteria: in three strains of $X$. oryzae pv. oryzae, in Acidovorax avenae pv. citrulli, and (a possibly inactive homolog) in Xanthomonas campestris pv. vesicatoria (Table 2). In contrast, no homologous genes have been detected in assembled sequences of $X$. oryzae pv. oryzicola or in $X$. campestris pv. campestris. All Pat-1 family members from subspecies sepedonicus and michiganensis, as well as the homologs from gram-negative bacteria, are potentially active serine proteases, as the active sites of serine proteases are conserved across all family members. $X$. campestris pv. vesicatoria ORF Xcv4424 and Xcv4425, which seem to represent N-terminus and C-terminus ends of an inactivated homolog, also have intact serine protease active sites. All species but those of genus Clavibacter seem to contain only one pat-1 homolog. Thus, the expansion of the pat-1 family seems to be $C$. michiganensis-specific. Intriguingly, like CMS2989 (encoding Chp-7) and other pat-1 homologs in C. michiganensis (Bentley et al. 2008; Gartemann et al. 2008), the non-Clavibacter pat-1 family members also seem to be located in genomic areas that show signs of putative mobile or pathogenicity islands; the pat-1 homologs in $X$. oryzae pv. oryzae strains are all located immediately between IS elements or transposase-like genes and the putatively inactivated homolog in $X$. campestris pv. vesicatoria $85-11$ is situated $1.3 \mathrm{~kb}$ upstream of a putative avirulence gene, avrRxo1. Similarly, pat-1 of L. xyli pv. xyli (Lxx24245) is downstream from a phage-related lysozyme lys $L$ and approximately $4 \mathrm{~kb}$ upstream from a putative hemagglutinin hemolysin-like protein (Lxx24270) and a phage-related inte-

Table 2. Non-Clavibacter members of the Pat 1 protein family and their similarity to Chp-7

\begin{tabular}{lccc}
\hline Organism & GenBank accession, locus tag, gene & Homology/similarity (\%) & Probability \\
\hline Leifsonia xyli subsp. xyli CTCB07 & YP_063162.1, Lxx24245, pat1 & $30 / 42$ & $1 \mathrm{e}-23$ \\
Xanthomonas oryzae pv. oryzae KACC10331 & AAW74240 & $35 / 48$ & $9 \mathrm{e}-28$ \\
Xanthomonas oryzae pv. oryzae PX099A & ACD60846 & $35 / 48$ & $7 \mathrm{e}-28$ \\
Xanthomonas oryzae pv. oryzae MAFF311018 & YP_449930 & $35 / 48$ & $7 \mathrm{e}-28$ \\
X. campestris pv. vesicatoria 85-10 & CAJ26155.1, xcv4424 & $43 / 57$ & $7 \mathrm{e}-21$ \\
X. campestris pv. vesicatoria $85-10$ & CAJ26156.1, xcv4425 & $35 / 42$ & 0.69 \\
Acidovorax avenae pv. citrulli & ABM33827.1 & $34 / 48$ & $2 \mathrm{e}-27$ \\
\hline
\end{tabular}


grase (Lxx24280). The percent GC of pat- 1 of L. xyli subsp. $x y l i$ is also remarkably low, only $56 \%$ as compared with the average $67.7 \%$ of the genome.

Secreted proteases have been implicated in virulence of several plant-pathogenic bacteria, but exact roles in pathogenesis are generally unknown. Xanthomonas campestris pv. campestris secretes two extracellular proteases, Prt1 (serine protease of subtilisin-type) and Prt2 (metalloprotease), which are required for full virulence in conditions mimicking natural infection (Dow et al. 1990). Also, in X. campestris pv. oryzae, protease production has been shown to be needed for virulence, although the identity of the protease is not known ( $\mathrm{Xu}$ and Gonzalez 1989). In soft rot enterobacteria and in the fire blight pathogen, Erwinia amylovora, metalloprotease production has been shown to promote cell-wall maceration or tissue colonization during virulence (Marits et al. 1999; Zhang et al. 1999).

Effector proteins secreted by the type III-secretion (T3S) system are pivotal for virulence of several gram-negative pathogens. Effector proteins enhance virulence in host plants but are often recognized in resistant plant species or cultivars. Several of these effectors have recently been shown to be proteases and to require protease activity for their virulence or HR-inducing ability. AvrPphB of Pseudomonas syrngae pv. phaseolicola is a member of the papain family of serine proteases and depends on an intact catalytic core for its HR-inducing activity (Shao et al. 2002). XopD and several other YopJ family members of effector proteins are proteases that target SUMOylated host proteins (Hotson and Mudgett 2004) and suppress host defense signaling. Perhaps not surprisingly, there is no evidence of a T3S system in any gram-positive plant pathogen. Gram-positive bacteria secrete most proteins through the general secretion (Sec) apparatus. Others are secreted via the twin arginine transport system (McDonough et al. 2005). Some bacteria possess novel mechanisms for protein secretion and translocation of effectors into their hosts, a functional equivalent to the T3S system (Madden et al. 2001; Pallen 2002; Rosch and Caparon 2005). It is presumed but has not yet been demonstrated that members of the Pat-1 family are secreted through a Sec-dependent pathway. Furthermore, it is not known whether any proteins secreted by Clavibacter spp. are translocated into plant cells.

Our studies provide insights on the molecular basis for plant-Clavibacter interactions leading to HR or disease. C. mi-

Table 3. Bacterial strains and plasmids used in the study

\begin{tabular}{|c|c|c|}
\hline Strain & $\begin{array}{c}\text { Relevant genotype and/or } \\
\text { phenotype }^{\text {a }}\end{array}$ & $\begin{array}{l}\text { Reference or } \\
\text { source }\end{array}$ \\
\hline \multicolumn{3}{|l|}{ Bacteria } \\
\hline \multicolumn{3}{|c|}{ Clavibacter michiganesis subsp. sepedonicus } \\
\hline R10 & $\begin{array}{l}\text { Wild-type strain, hypersensitive- } \\
\text { response-positive, virulent, } \\
\text { nonmucoid }\end{array}$ & Nissinen 2000 \\
\hline L11E & $\mathrm{Tn} 1409 \mathrm{C} \beta$ mutant of $\mathrm{R} 10, \mathrm{cmx}^{\mathrm{r}}$ & This work \\
\hline O10A & $\operatorname{Tn} 1409 \mathrm{C} \beta$ mutant of $\mathrm{R} 10, \mathrm{cmx}^{\mathrm{r}}$ & This work \\
\hline L11EpPat-1 & $\begin{array}{l}\text { L11E transformed with } \\
\text { pHNPat } 1 \mathrm{Cms}\end{array}$ & This work \\
\hline L11EpPat-3 & $\begin{array}{l}\text { L11E transformed with } \\
\text { pHNPat } 1 \mathrm{Cms}\end{array}$ & This work \\
\hline L11EpPat-4 & $\begin{array}{l}\text { L11E transformed with } \\
\text { pHNPat } 1 \mathrm{Cms}\end{array}$ & This work \\
\hline \multicolumn{3}{|l|}{ Plasmids } \\
\hline pKGT452C $\beta$ & $\begin{array}{l}\text { Vector for delivery of } \operatorname{Tn} 1409 \mathrm{C} \beta \text {, } \\
\operatorname{amp}^{\mathrm{r}} \text { (vector) } \mathrm{cmx}^{\mathrm{r}}(\mathrm{Tn})\end{array}$ & $\begin{array}{l}\text { Gartemann and } \\
\text { Eichenlaub } 2001\end{array}$ \\
\hline pHN216 & $\begin{array}{l}\text { Clavibacter-Escherichia coli shuttle } \\
\text { vector, neo }{ }^{\mathrm{r}}\end{array}$ & Laine et al. 1996 \\
\hline pHNPat1Cms & $\begin{array}{l}\text { chp-7 and predicted promoter in } \\
\text { pHN216, neo }\end{array}$ & This work \\
\hline
\end{tabular}

chiganensis subsp. sepedonicus is a highly specialized plant biotrophic necrogen that has evolved to thrive within a relatively narrow ecological niche, that of the potato apoplast. To accomplish this, it likely produces extracellular enzymes capable of degrading plant cell walls and other compounds in the apoplast as sources of nutrients. It must also be able to somehow circumvent or avoid eliciting plant defense responses. Secreted proteins or those proteins attached to the surface of the bacterial cell would be the first point of contact between this pathogen and its host. Evidence presented here with subspecies sepedonicus and elsewhere with subsp. michiganensis demonstrates that certain pat- 1 homologs are important in determining the outcome of coryneform-plant interactions. The Pat-1 family constitutes a conserved pathway in plant pathogenesis that is distinct from the more well-studied T3S-dependent pathway. Continued study of pat-l homologs in C. michiganensis is essential for gaining a better understanding of the specific molecular events leading to disease or HR elicitation by this group of largely host-specific plant pathogens. Such studies could also contribute generally to a comprehensive understanding of pathway diversity underlying plant-microbe interactions.

\section{MATERIALS AND METHODS}

Bacterial strains and growth conditions.

The bacterial strains and plasmid constructs used in the study are listed in Table 3. Routinely, C. michiganensis subsp. sepedonicus strains were grown at 23 to $26^{\circ} \mathrm{C}$ on YPG $(0.5 \%$ yeast extract, $0.5 \%$ bacto peptone, $1.0 \%$ glucose, all wt/vol) or, prior to HR tests, on YGM (De Boer and Copeman 1980). All cultures were started from glycerol stocks stored at -20 or $-80^{\circ} \mathrm{C}$. Media were supplemented with $40 \mu \mathrm{g}$ of neomycin per milliliter and $2.5 \mu \mathrm{g}$ of chloramphenicol per milliliter, as necessary. Escherichia coli Top10F' (Invitrogen, Carlsbad, CA, U.S.A.) was grown at $37^{\circ} \mathrm{C}$ in Luria-Bertani medium containing $150 \mu \mathrm{g}$ of ampicillin per milliliter. All selective plates used for screening positively transformed $E$. coli colonies had $80 \mu \mathrm{l}$ of $20 \mathrm{mg} / \mathrm{ml} \mathrm{X}$-gal and $10 \mu \mathrm{l}$ of $0.5 \mathrm{M}$ isopropyl- $\beta$-D-thiogalactoside (IPTG) spread on the surface.

\section{Plant assays.}

Virulence of $C$. michiganensis subsp. sepedonicus mutants was evaluated in eggplant and in potato. For eggplant assays, stems of 14- to 18-day-old (first true leaf emerging) eggplants (Solanum melongena cv. Black Beauty) were inoculated with bacterial suspensions (approximately $10^{8} \mathrm{CFU} / \mathrm{ml}$ ) and were rated for disease symptoms 14 days after inoculation (dpi), as described by Nissinen and associates (1997). Eight to twelve plantlets were used per treatment, and each assay was repeated four times. Bacterial population densities in eggplants were determined 14 dpi. Preweighed stem sections were surface sterilized and ground in sterile $50 \mathrm{mM} \mathrm{KPi} \mathrm{(pH} \mathrm{7.0).} \mathrm{Serial} \mathrm{di-}$ lutions of homogenates were plated onto YPGA (solid YPG medium with $1.5 \%$ [wt/vol] agar plates), and bacterial population densities were calculated after 1 week at room temperature (approximately $23^{\circ} \mathrm{C}$ ). Solanum tuberosum cv. Superior was used to evaluate the virulence of the mutants in potato, essentially as described by Brown and associates (2002). Roots of 4-week-old micropropagated plantlets were soaked in bacterial suspensions adjusted to an optical density at $620 \mathrm{~nm}$ $\left(\mathrm{OD}_{620}\right)=0.2$ in $50 \mathrm{mM} \mathrm{KPi}$ or in sterile buffer for a negative control. Plantlets were transplanted in soil-peat mix and were grown at $22^{\circ} \mathrm{C}$ in a growth chamber. Symptoms were evaluated at $77 \mathrm{dpi}$. Tests for HR on tobacco were performed as described by Nissinen and associates (1997). Routinely, tobacco plants (Nicotiana tabacum cv. Samsun) were grown in a greenhouse 
to the six- to eight-leaf stage prior to being transferred to a growth chamber $\left(23^{\circ} \mathrm{C}\right)$. Leaves were treated by punching a small hole in the leaf blade with a sterile injection needle, followed by infiltration with a needleless, 1-ml syringe containing bacterial suspensions at $\mathrm{OD}_{620}=0.8$. Responses were routinely scored $24 \mathrm{~h}$ postinoculation (hpi) and, during the Tn mutant library screening, also $48 \mathrm{hpi}$. Statistical tests involving disease severity and population densities were performed by ANOVA (analysis of variance) followed by Tukey's HSD (honestly significant differences) test.

\section{Construction of Tn mutant library.}

A Tn mutant library of highly virulent, nonmucoid wild-type strain R10 was constructed following the Tn-based mutagenesis methods of Kirchner and associates (2001), using arthrobacterial Tn1409C $\beta$ (Gartemann and Eichenlaub 2001). The methods were modified for $C$. michiganensis subsp. sepedonicus. To obtain electrocompetent cells, cultures were pregrown from frozen stocks on YGM plates for 2 days, were resuspended in YGM liquid medium with 0.2 to $0.4 \%$ (wt/vol) glycine to an $\mathrm{OD}_{540}$ of 0.05 , and were grown at $25^{\circ} \mathrm{C}$, with vigorous shaking to an $\mathrm{OD}_{540}$ of 0.2 to 0.5 . The cells were washed three times in sterile $10 \%$ glycerol, were resuspended to an $\mathrm{OD}_{540}$ of 20 to 50 , and were electroporated with pKGT452C $\beta$ with the electroporation parameters set to $25 \mu \mathrm{F}, 600 \mathrm{ohms}$, and 12.5 to $15 \mathrm{~V} / \mathrm{cm}$. Voltages above $15 \mathrm{~V} / \mathrm{cm}$ reduced transformation rates.

\section{Characterization of Tn library.}

A modified cetyltrimethylammonium bromide purification procedure was used to produce template suitable for direct Big Dye terminator v3.1 cycle sequencing (Big Dye terminator cycle sequencing kit from Applied Biosystems, Foster City, CA, U.S.A.). The left ISN2 or the right ISC2 primer (direction relative the $\mathrm{Tn} 1409 \mathrm{C} \beta$ ) was used to produce the sequence (Kirchner et al. 2001). The sequencing primer was GGAACCTCACCAACTACATAGC for ISC2 and CATGCAG TTGCGCCCACTACAC for ISN2. Only-high quality sequence reads with high similarities to reference strain CMS ATCC 33113 (blastn scores of less than 1e-100 or GFF2 scores $>500$ or both) were evaluated further. The sequences were localized within the complete genome sequences of reference strain C. michiganensis subsp. sepedonicus ATCC33113 (Bentley et al. 2008) and were visualized in Artemis (Parkhill et al 2000). Sequences for pCS1 (accession number AM849035) and pCSL1 (accession number AM8490367) were obtained from the European Molecular Biology Laboratory-European Bioinformatics Institute website.

\section{Arbitrary PCR.}

The arbitrary PCR protocol was modified from O'Toole and Kolter (1998). Total genomic DNA of C. michiganensis subsp. sepedonicus mutants were isolated as described by Comai and Kosuge (1983), suspended in water and boiled 2 min before PCR. The first-round primers were Tn1409out, unique to the 25-bp right inverted repeats of Tn1409C $\beta$ and ARB1, designed to hybridize to an arbitrary sequence on the chromosome. For the second round, nested primers were used: Tn1409nest, unique to the Tn, and ARB2, identical to the 5' end of the arbitrary primer ARB1. The oligonucleotide sequences of the four primers are: Tn1409out: ACTACACCCTCAATTCTGAA, ARB1: GGCCACGCGTCGACTAGTACNNNNNNNNNNGA TAT. Tn1409nest: TACACCCTCAATTCTGAAGAGCC, and ARB2: GGCCACGCGTCGACTAGTAC. The PCR products were cloned into TOPO-TA cloning vector (Invitrogen Life Technologies, Carlsbad, CA, U.S.A) and were sequenced. The sequences were then localized on the assembled $C$. michiganen- sis subsp. sepedonicus genomic sequence available on the Sanger Center C. michiganensis subsp. sepedonicus website.

\section{PCR to detect and analyze CMS2989.}

PCR primers Pat1F (CGT GCA TCG CTC CCT GTG) and Pat1R (TGA CGA CAG GTC CCC CAG) were used to check for the presence of CMS2989 in wild-type strains of C. michiganensis subsp. sepedonicus. For confirming location and orientation of Tn1409C $\beta$ in mutants L11E and O10A, primers Pat1F, Pat1R, and TnpAout (ATC CAA GGA AAG AAG CTC ATG C) were used in pairs TnpAOut-Pat1R and Tnp1-Pat1F. Pat1F and Pat1R were located upstream and downstream, respectively, of the Tn insertion sites in chp-7 of both mutants, and TnpAout was a 24-bp area located from bp 1,019 to 1,042 of the tnpA region in Tn1409C $\beta$ (Gartemann and Eichenlaub 2001).

\section{Southern hybridization.}

Chromosomal DNA of R10 and mutants L11E and O10A was isolated as described in Comai and Kosuge (1983), and then digested with $\mathrm{BamH} 1$ at $37^{\circ} \mathrm{C}$ for $6 \mathrm{~h}$ and resolved by electrophoresis in $1 \%(\mathrm{wt} / \mathrm{vol})$ agarose gels. For detection of both the Tn1409C $\beta$ and the mutant $c h p-7$ genes, two groups of samples from the same digested DNA were run on one gel to get identical blots. Southern blotting to nylon membranes was done overnight as described by Sambrook and associates (1989). Probes for detection of chp-7 (probe CMS2989int, 595 bp) and Tn1409C $\beta$ (probe 1409, $581 \mathrm{bp}$ ) were amplified by PCR from R10 and Tn1409C $\beta$ with primer pairs Pat1F-Pat1R (sequences above) and TnpAF-TnpAR, respectively (TnpAF: TGA CGA CAG GTC CCC CAG, TnpAR: CAG TGT CTG TAC CCT GAT CGT GC). The probes were digoxigenin (DIG)-labeled, by the addition of $0.5 \mu \mathrm{l}$ of DIG-conjugated UTP included in each PCR reaction $(50 \mu \mathrm{l})$. Hybridization was done overnight following a protocol by Sambrook and associates (1989), modified as follows. The probes were denatured by heating in boiling water for 2 min prior to hybridizaton. All hybridizations and posthybridization washes were carried out at $68^{\circ} \mathrm{C}$ in a hybridization oven (MIDI DUAL 14, Hybaid Ltd., Teddington, Meddlesex, U.K.). Detection of the hybridization results was done by Chemiluminesence detection kit (Roche Diagnostics, Mannheim, Germany) according to the manufacturer's instructions.

\section{RT-PCR.}

We designed three primer pairs with a common forward primer and reverse primers specific for full-size transcript and both of the truncated mutant transcripts as follows:

forward primer

(F1) TCTGTGAGAATCCCACA (binds to nucleotides (nt) 10 to 26 of chp-7);

reverse primers

R(wt) AGGTCTCATCTCCTGAAC (binding site gttcagga gatgagacct, $65 \mathrm{nt}$ upstream of predicted translation stop)

$\mathrm{R}(\mathrm{O})$ AAATCTCCCGAGCATCTG (binding site GATGC TCGGGAGATTTT $22 \mathrm{nt}$ upstream of the Tn insertion site in O10A) and

R(L) GCGGTCGCTACATATCG (binding site cgatatgtag cgaccgc $41 \mathrm{nt}$ upstream of the Tn insertion site in L11E).

For RNA extraction, the bacteria were cultivated $48 \mathrm{~h}$. The bacteria were harvested by centrifugation, and cells were broken by FastPrep (MP Biomedicals, Illkirch, France). Total RNA was extracted with RNeasy plant mini kit (Qiagen, Hilden, Germany). RNA $(1 \mu \mathrm{g})$ was treated with $2 \mathrm{U}$ DNase (Promega, Madison, WI, U.S.A.) for $3 \mathrm{~h}$ at $37^{\circ} \mathrm{C}$. The DNase reaction was stopped and RT-PCR was performed by adding $200 \mathrm{ng}$ of random hexamers. The reaction was incubated at $70^{\circ} \mathrm{C}$ for 10 
min and was then snap cooled on ice. The following ingredients were added to each sample: reaction buffer $(1 \times)$, deoxynucleoside triphosphates (0.5 $\mathrm{mM}$ each), dithiothreitol (10 $\mathrm{mM}$ ), RNasin (20 U, Promega), and reverse transcriptase (400 $\mathrm{U}$, Promega). cDNA synthesis was carried out by incubating first for $10 \mathrm{~min}$ at $25^{\circ} \mathrm{C}$ and then for $90 \mathrm{~min}$ at $37^{\circ} \mathrm{C}$. The reaction was stopped by incubating for $10 \mathrm{~min}$ at $70^{\circ} \mathrm{C}$. The cDNA was diluted by the addition of $80 \mu \mathrm{l}$ of $\mathrm{H}_{2} \mathrm{O}$ to each sample, and $3 \mu \mathrm{l}$ was used as a template for $25-\mu \mathrm{l}$ PCR reactions. PCR was performed with Taq polymerase (Promega), following the instructions of the manufacturer. A Dnase-treated RNA sample was used as a control to detect putative chromosomal DNA contamination.

\section{Complementation of L11E mutant strain with CMS2989.}

The patl gene and its promoter site from R10 was amplified with PCR, using primers Pat1CmsF (CGTATCCGATGAGCT GTCCTG) and Pat1CmsR (AAATATTTCACACCATCCGCT GAG) as forward and reverse primers, respectively. The PCR fragment was A-tailed with Taq polymerase and was cloned in TOPO-TA cloning vector (Invitrogen Life Technologies). The insert and pHN216 plasmid vector were cut with EcoRI and $S s p$ I and were purified (QIAgen PCR purification kit) and ligated. The correct structure of the resulting construct, pPat, was verified by PCR and sequencing, and the construct was electroporated into electrocompetent L11E cells. Preparation of electrocompetent cells and the transformation parameters were as described above for construction of the Tn library, with the exception that no glycine was added to growth media. The cloning vector pHN216 was used to construct a vectorcontrol strain. Transformants were plated onto YPGA supplemented with $40 \mu \mathrm{g}$ of neomycin per milliliter. The presence of appropriate plasmids in transformants was confirmed by PCR.

\section{Expression of Pat1 in E. coli.}

pat-1 was amplified from R10 with primer pair Pat1ECF (CCGCCCATGGCAGTCGATCGCA) and Pat1ECR (GCCGC CATGGTCCGCAGCTACGT). The forward primer was designed to exclude the leader peptide of CMS2989 and was modified to ensure correct frame and expression in $E$. coli. The stop codon included in the reverse primer omitted the pQE-60 derived histidine tag from the fusion protein. The PCR fragment was cloned in TOPO-TA cloning vector (Invitrogen Life Technologies, Carlsbad, CA, U.S.A.) and, after propagation in E. coli DH5 $\alpha$, was transferred into pQE-60 (Qiagen) with NcoI (Fermentas, Vilnius, Lithuania). The correct orientation of the insert in pQE-60 was verified by PCR, and the resulting construct was named pPat1EC. For protein expression, the $E$. coli M15 was chemically transformed with pPat $1 \mathrm{CmsEC}$ and, for vector control, with pQE-60 as described by Sambrook and associates (1998). Protein production was induced with 0.1 to $1 \mathrm{mM}$ IPTG.

\section{ACKNOWLEDGMENTS}

The authors thank M. Kilpinen and M. German-Kinnari for excellent technical assistance. This project was funded by Academy of Finland Project 206219, the Niemi-Foundation, the Colorado Agricultural Experiment Station, and the Minnesota Agricultural Experiment Station.

\section{LITERATURE CITATIONS}

Bentley, S. D., Corton, C., Brown, S. E., Barron, A., Clark, L., Doggett, J., Harris, B., Ormond, D., Quail, M. A., May, G., Francis, D., Knudson, D., Parkhill, J., and Ishimaru, C. A. 2008. Genome of the actinomycete plant pathogen Clavibacter michiganensis subsp. sepedonicus suggests recent niche adaptation. J. Bacteriol. 190:2150-2160.

Brown, S. E., Reilley, A. A., Knudson, D. L., and Ishimaru, C.A. 2002.
Genomic fingerprinting of virulent and avirulent strains of Clavibacter michiganensis subspecies sepedonicus. Curr. Microbiol. 44:112-119.

Burger, A., Gräfen, I., Engemann, J., Niermann, E., Pieper, M., Kirchner, O., Gartemann, K.-H., and Eichenlaub, R. 2005. Identification of homologues to the pathogenicity factor Pat-1, a putative serine protease of Clavibacter michiganensis subsp. michiganensis. Microbiol. Res. 160:417-427.

Comai, L., and Kosuge, T. 1983. Transposable element that causes mutations in a plant pathogenic Pseudomonas sp. J. Bacteriol. 154:1162-1167

Davis, M. J., Gillaspie, Jr., A. G., Vidaver, A. K., and Harris, R. W. 1984 Clavibacter: A new genus containing some phytopathogenic coryneform bacteria, including Clavibacter xyli subsp. xyli sp. nov., subsp. nov. and Clavibacter xyli subsp. cynodontis subsp. nov. , pathogens that cause ratoon stunting disease of sugarcane and bermudagrass stunting disease. Int. J. Syst. Bacteriol. 34:107-117.

De Boer, S. H., and Copeman, R. J. 1980. Bacterial ring rot testing with the indirect fluorescent antibody staining procedure. Am. Potato J. 57:457-465.

Dow, J. M., Clarke, B. R., Milligan, D. E., Tang, J. L., and Daniels, M. J. 1990. Extracellular proteases from Xanthomonas campestris pv. campestris, the black rot pathogen. Appl. Environ. Microbiol. 56:29942998

Dreier, J., Meletzus, D., and Eichenlaub, R. 1997. Characterization of the plasmid encoded virulence region pat-1 of phytopathogenic Clavibacter michiganensis subsp. michiganensis. Mol. Plant-Microbe Interact. 10:195-206.

Eichenlaub, R., Gartemann, K.-H., and Burger, A. 2006. Clavibacter michiganensis, a group of gram-positive phytopathogenic bacteria. Pages 385-421 in: Plant-associated bacteria, S. S. Gnanamanickam, ed. Springer Netherlands,

Elphinstone, J. G. 2004. Page 45 in: Potato ring rot (Clavibacter michiganensis subsp. sepedonicus): The facts. British Potato Council, Oxford, U.K.

Gartemann, K.-H., and Eichenlaub, R. 2001. Isolation and characterization of IS1409, an insertion element of 4-chlorobenzoate-degrading Arthrobacter sp. strain TM1 and development of a system for transposon mutagenesis. J. Bacteriol. 183:3729-3736.

Gartemann, K., Abt, B., Bekel, T., Burger, A., Engemann, J., Flugel, M. Gaigalat, L., Goesmann, A., Grafen, I., Kalinowski, J., Kaup, O., Kirchner, O., Krause, L., Linke, B., McHardy, A., Meyer, F., Pohle, S., Ruckert, C., Schneiker, S., Zellermann, E.-M., Puhler, A., Eichenlaub, R., Kaiser, O., and Bartels, D. 2008. The genome sequence of the tomato-pathogenic actinomycete Clavibacter michiganensis subsp. michiganensis NCPPB382 reveals a large island involved in pathogenicity. J. Bacteriol. 190:2138-2149.

Heath, M. C. 2000. Hypersensitive response-related death. Plant Mol. Biol. 44:321-334.

Holt, J. G., Krieg, N. R., Sneath, P. H. A., Staley, J. T., and Williams, S. T. 1994. Pages 571-591 in: Bergey's Manual of Determinative Bacteriology, 9th ed. Williams and Wilkins, Baltimore.

Holtsmark, I., Takle, G. W., and Brurberg, M. B. 2008. Expression of putative virulence factors in the potato pathogen Clavibacter michiganensis subsp. sepedonicus during infection. Arch. Microbiol. 189:131-139.

Hotson, A., and Mudgett, M. B. 2004. Cysteine proteases in phytopathogenic bacteria: Identification of plant targets and activation of innate immunity. Curr. Opin. Plant Biol. 7:384-390

Kirchner, O., Gartemann, K.-H., Zellermann, E.-M., Eichenlaub, R., and Burger, A. 2001. A highly efficient transposon mutagenesis system for the tomato pathogen Clavibacter michiganensis subsp. michiganensis. Mol. Plant-Microbe Interact. 14:1312-1318.

Laine, M. J., Nakhei, H., Dreier, J., Lehtilä, K., Meletzus, D., Eichenlaub, R., and Metzler, M. C. 1996. Stable transformation of the gram-positive bacterium Clavibacter michiganensis subsp. sepedonicus with several cloning vectors. Appl. Environ. Microbiol. 62:1500-1506.

Louws, F. J., Bell, J., Medina-Mora, C. M., Smart, C. D., Opgenorth, D. Ishimaru, C. A., Hausbeck, M. K., de Bruijn, F. J., and Fulbright, D. W. 1998. rep-PCR-mediated genomic fingerprinting: A rapid and effective method to identify Clavibacter michiganensis. Phytopathology 88:862868.

Madden, J. C., Ruiz, N., and Caparon, M. 2001. Cytolysin-mediated translocation (CMT): A functional equivalent of Type III secretion in grampositive bacteria. Cell 104:143-152.

Marits, R., Koiv, V., Laasik, E., and Mäe, A. 1999. Isolation of an extracellular protease gene of Erwinia carotovora subsp. carotovora strain SCC3193 by transposon mutagenesis and the role of protease in phytopathogenicity. Microbiology 145:1959-1966.

McDonough, J. A., Hacker, K. E., Flores, A. R., Pavelka, M. S., Jr., and Braunstein, M. 2005. The twin-arginine translocation pathway of Mycobacterium smegmatis is functional and required for the export of mycobacterial beta-lactamases. J. Bacteriol. 187:7667-79. 
Monteiro-Vitorello, C. B., Camargo, L. E. A., Van Sluys, M. A., Kitajima, J. P., Truffi, D., do Amaral, A. M., Harakava, R., de Oliveira, J. C. F. Wood, D., de Oliveira, M. C., Miyaki, C., Takita, M. A., da Silva, A. C. R., Furlan, L. R., Carraro, D. M., Camarotte, G., Almeida N. F., Jr., Carrer, H., Coutinho, L. L., El-Dorry, H. A., Ferro, M. I. T., Gagliardi, P. R., Giglioti, E., Goldman, M. H. S., Goldman, G. H., Kimura, E. T., Ferro, E. S., Kuramae, E. E., Lemos, E. G. M., Lemos, M. V. F., Mauro, S. M. Z., Machado, M. A., Marino,C. L., Menck, C. F., Nunes, L. R., Oliveira, R. C., Pereira, G. G., Siqueira, W., de Souza, A. A., Tsai, S. M., Zanca, A. S., Simpson, A. J. G., Brumbley, S. M., and Setúbal, J. C. 2004. The genome sequence of the grampositive sugarcane pathogen Leifsonia xyli subsp. xyli. Mol. PlantMicrobe Interact. 17:827-836.

Nissinen, R. 2000. Gram positive phytopathogenic bacterium Clavibacter michiganensis subsp. Sepedonicus: Virulence factors and interactions with plants. Page 114. Annales Universitatis Turkuensis ser. AII, Turku, Finland.

Nissinen, R., Lai, F. M., Laine, M. J., Bauer, P. J., Reilley, A. A., Li, X., De Boer, S. H., Ishimaru C. A., and Metzler, M. C. 1997. Clavibacter michiganensis subsp. sepedonicus elicits a hypersensitive response in tobacco and secrets hypersensitive response-inducing protein(s). Phytopathology 87:678-684.

Nissinen, R., Kassuwi, S., Peltola, R., and Metzler, M. C. 2001. Strains of C. michiganensis subsp. sepedonicus impaired in cellulase production or induction of hypersensitive response can partially compensate each other's deficiencies to enhance virulence in planta. Eur. J. Phytopathol. 107:175-182.

O'Toole, G., and Kolter, R. 1998. Initiation of biofilm formation in Pseudomonas fluorescens WCS365 proceeds via multiple, convergent signaling pathways: A genetic analysis. Mol. Micro. 28:449-461.

Pallen, M. J. 2002. The ESAT-6/WXG100 superfamily-and a new grampositive secretion system? Trends Microbiol. 10:209-212.

Parkhill, J., Achtman, M., James, K. D., Bentley, S. D., Churcher, C., Klee, S. R., Morelli, G., Basham, D., Brown, D., Chillingworth, T., Davies, R. M., Davis, P., Devlin, K., Feltwell, T., Hamlin, N., Holroyd, S., Jagels, K., Leather, S., Moule, S., Mungall, K., Quail, M. A., Rajandream, M.
A., Rutherford, K. M. Simmonds, M. Skelton, J. Whitehead, S. Spratt, B. G., and Barrell, B. G. 2000. Complete DNA sequence of a serogroup A strain of Neisseria meningitidis Z2491. Nature 404:502-506.

Rosch, J. W., and Caparon, M. G. 2005. The ExPortal: An organelle dedicated to the biogenesis of secreted proteins in Streptococcus pyogenes. Mol. Microbiol. 58:959-68.

Sambrook, J., Fritsch, E. F., and Maniatis, T. 1989 Molecular Cloning: A Laboratory Manual. 2nd ed. Cold Spring Harbor Laboratory Press, Cold Spring Harbor, N.Y., U.S.A.

Shao, F., Merritt, P. M., Bao,Z., Innes R. W., and Dixon, J. E. 2002. A Yersinia effector and a Pseudomonas avirulence protein define a family of cysteine proteases functioning in bacterial pathogenesis. Cell 109:575-588.

Stork, I., Gartemann, K.-H., Burger, A., and Eichenlaub, R. 2008. A family of serine proteases of Clavibacter michiganensis subsp. michiganensis: $\operatorname{chpC}$ plays a role in colonization of the host plant tomato. Mol. Plant Pathol. 9:599-608.

van der Wolf, J. M., van Beckhoven, J. R. C. M., Hukkanen, A., Karjalainen, R., and Müller, P. 2005. Fate of Clavibacter michiganensis ssp. sepedonicus, the causal organism of bacterial ring rot of potato, in weeds and field crops. J. Phytopathol. 153:358-365.

Xu, G.W., and Gonzalez, C.F. 1989. Evaluation of TN4431-induced protease mutants of Xanthomonas campestris pv. oryzae for growth in plants and pathogenicity. Phytopathol. 79:1210-1215.

Zhang, Y., Bak, D. D., Heid, H., and Geider, K. 1999. Molecular characterization of a protease secreted by Erwinia amylovora. J. Mol. Biology 289:1239-1251.

\section{AUTHOR-RECOMMENDED INTERNET RESOURCES}

J. Craig Venter Institute website: www.tigr.org/db.shtml

European Molecular Biology Laboratory-European Bioinformatics Institute: www.ebi.ac.uk/genomes/plasmid.html.

The Sanger Center $C$. michiganensis subsp. sepedonicus website: www.sanger.ac.uk/Projects/C_michiganensis 